\title{
Maria Gołębiewska
}

\section{Powtórzenie w myśli Sørena Kierkegaarda - opowieść a przypowieść}

ABSTRACT. Gołębiewska Maria, Powtórzenie w myśli Sørena Kierkegaarda - opowiesć a przypowieść [Repetition in the ideas of Søren Kieerkegard]. „Przestrzenie Teorii” 8, Poznań 2008, Adam Mickiewicz University Press, pp. 123-141. ISBN 978-83-232187-5-3. ISSN 1644-6763.

In this text the author describes briefly Kierkegaard's conception of existence, which has been juxtaposed by him with the reinterpreted conception of essence and of the existing. Kierkegaard defined existence referring to different orders of representation, first of all to the spoken and written language. He considered existence - always individual and particular - as an object of personal existential choice. This choice concerns, at the same time, the way of individual existence (the stadium of life) and the individual identity. That is why in Kierkegaard's reflection is so important the reference to individual identity and to its grasp in narration - in the mythical parable and in the story concerning everyday life. The problems of existence, identity and their grasp in representation are connected with the Kierkegaardian question of repetition, which is also discussed in this study.

Jednym z podstawowych zagadnień filozofii Sørena Kierkegaarda jest powtórzenie jako pewna figura językowa i retoryczna, a zarazem jako element narracji, przede wszystkim opowieści biograficznych. Problematyka ta jest rozwijana $w$ tekście, a poprzedza ją omówienie podstawowych tez Kierkegaarda, dotyczących egzystencji. Trzeba podkreślić, że łączył on kategorię egzystencji z kwestiami tożsamości jednostkowej.

\section{Egzystencja i tożsamość jednostkowa}

Kierkegaard wielokrotnie podkreśla prymat jednostkowości i tego, co jedyne, wobec tego, co ogólne. „Kategoria "pojedynczego" ma u Duńczyka specyficzne znaczenie; jest to ten, który samotnie, niczym patriarcha Abraham, stoi w obliczu Boga, przeżywając swój dramat"1. Wedle Kierkegaarda to szczególnie „paradoks wiary” polega „na tym, że jednostka jest wyższa od tego, co ogólne"2, a co ujmuje się systematycznie, dogma-

I S. Kierkegaard, Okruchy filozoficzne. Chwila, przekł. K. Toeplitz, Warszawa 1988 , s. 137.

2 Tenże, Bojaźń i drżenie. Choroba na śmierć, przekł. J. Iwaszkiewicz, Warszawa 1982, s. 74 . 
tycznie czy logicznie w znaczeniu Heglowskim jako - przeciwnie - relację jednostkowego wobec tego, co ogólne, przewyższające to, co indywidualne. Kierkegaard dalej argumentuje: ,jednostka - że przypomnę tu jeszcze osobliwszą dogmatyczną dystynkcję, rzadko dziś dostrzeganą - określa swój stosunek do tego, co ogólne, poprzez swój stosunek do absolutu", czyli de facto do tego, co jednostkowe i jedyne zarazem, nie zaś ujmuje jak to opisuje Hegel - „swój stosunek do absolutu przez stosunek do tego, co ogólne"3.

Pojęcie egzystencji pojawiło się w pisarstwie Johannesa Georga Hamanna i Kierkegaard najprawdopodobniej przejął je, nadając mu „własną, oryginalną treść". Kierkegaard „używa takich wyrażeń, jak: egzystowanie (at existere), egzystencja (Existents), a także Tilvaerelse, czyli istnienie. Termin ten Antoni Szwed proponuje ujmować w języku polskim jako „bycie konkretnym bytem, czy byciem tego oto"4. Autorzy poprzedzający Kierkegaarda nie mówili wprost o egzystowaniu, choć milcząco zakładali "ten dynamiczny sposób bycia ducha"5. Antoni Szwed w swojej interpretacji myśli Kierkegaarda wielokrotnie podkreśla ową różnicę między zwykłym istnieniem a egzystencją, wymagającą zarazem pewnego poznawczego wglądu, wysiłku samorozpoznania się jednostki w egzystencji. Bowiem „człowiek jako konkretna jednostka istnieje niezależnie od tego, jak istnieje. Jest po prostu bytem faktycznie (realnie) istniejącym"6.

W Dzienniku Kierkegaard pisał: „Egzystencja jest egzaminem człowieka"7 (1854). Egzystencja jest bowiem następstwem decyzji, wyborów i działań człowieka, dających możliwość przejścia od istnienia w doczesnej immanencji świata Natury i człowieka (kultury, społeczności) do transcendencji tego, co sakralne. Sfera czy też rzeczywistość transcendencji obejmuje Boga - jego wiecznotrwałe istnienie utożsamiane (za Tomaszem Akwinatą) z jego istotą oraz idee, które tam nie tyle istnieją, co bytują. Z kolei istota człowieka jest określana przez Kierkegaarda jako dwoista - cielesna (materialna) oraz duchowa i jako taki dwoisty byt człowiek przynależy do sfery immanencji, posiadając zarazem możliwość uczestniczenia $w$ transcendencji na mocy własnego wyboru. Jednak wybór ten powinien spotkać się z wyborem Boga, z jego łaską, predestynacją do życia wiecznego $w$ sferze transcendencji. Wobec konieczności dokonania wyboru - wyboru siebie - okazywało się, że „nawet najbardziej

3 Tamże.

${ }^{4}$ A. Szwed, Między wolnościa a prawdq egzystencji. Studium myśli Sørena Kierkegaarda, Kęty 1999, s. 48.

5 Tamze.

${ }^{6}$ Tamże.

${ }^{7}$ S. Kierkegaard, Dziennik (wybór), przekł. A. Szwed, Lublin 1999, s. 101. 
niepozorna jednostka otrzymuje tym sposobem podwójne istnienie”8. „Jedno z nich przejawiało się w [istnieniu; dop. M.G.] zewnętrznym, w świecie społeczno-historycznym, poddanym różnego rodzaju koniecznościom, podporządkowującym jednostkę różnego rodzaju strukturom ogólnym"9. De facto ,jej działanie jest wkomponowane w porządek rzeczy, który leży u podstaw całości istnienia"10 $\mathrm{i}$ jest porządkiem transcendentnym.

Kierkegaard wielokrotnie podkreśla, że wiedza dotyczy istoty, zaś wiara dotyczy istnienia, ma jednak przy tym na myśli przede wszystkim to, co transcendentne. Istota transcendentna, czyli to, co idealne, dane jest naszemu poznaniu dzięki rozpoznaniu istotowości w przedmiotach znanych tu i teraz, w rzeczywistości immanentnej. Natomiast istnienie, a tym bardziej egzystencja, ściśle związana z niedostępną poznawczo sferą transcendencji, podlega zaledwie rozpoznaniu w naszym własnym jednostkowym trwaniu, o ile podejmiemy trud i decyzję o wyborze egzystencji. Wybór dotyczący egzystencji łączy się ze świadomością istnienia, a egzystencja jest to w pewnej mierze istnienie człowieka świadomego swego istnienia i samoświadomego, czyli posiadającego wiedzę na temat własnej istoty.

Jak pisze Kierkegaard, „egzystencja połączyła myślenie i egzystowanie”, czyli istnienie, będące przedmiotem świadomego wyboru i namysłu, a „egzystujący jest myślącym, więc istnieją dwie sfery: sfera abstrakcji i rzeczywistości. Czyste myślenie stanowi jeszcze trzecią sferę, całkiem nowo wymyśloną"11. To właśnie "egzystowanie jest dla egzystującego przedmiotem największego zainteresowania, a zainteresowanie egzystowaniem jest rzeczywistością"12. Zdaniem Kierkegaarda rzeczywistość nie da się określić „w języku abstrakcji”, bowiem „rzeczywistość jest inter=esse między” - realnością tu i teraz, ale zarazem jedynie „hipotetyczną jednością myślenia i bytu"13 jako pewną możliwością pomyślaną i abstrakcyjną.

Kierkegaard podkreśla złożoność ludzkiej istotowości, na istotę człowieka składa się bowiem to, co cielesne, doczesne, będące elementem sfery immanencji, oraz to, co duchowe, co prowadzi człowieka ku transcendencji i jest poniekąd fragmentem transcendencji w człowieku. Pisze

${ }^{8}$ S. Kierkega ard, Albo-albo, t. I-II, przekł. J. Iwaszkiewicz, K. Toeplitz, Warszawa 1982 , t. II, s. 234, tekst $O$ równowadze między tym, co estetyczne, i tym, co etyczne.

${ }^{9}$ E. Kasperski, Ironiczna antropologia. Rozdwojenie i podwojenie czlowieka u Kierkegaarda, „Studia Filozoficzne”, nr 4(293)/1990, s. 185.

${ }_{10} \mathrm{~S}$. Kierkegaard, Albo-albo, op. cit., t. II, s. 232.

11 S. Kierkegaard, Wybór tekstów, w: K. Toeplitz, Kierkegaard, Warszawa 1975, s. 275, tekst Co jest przedmiotem wiary?

12 Tamże.

13 Tamże. 
on, że ludzka „egzystencja jest syntezą tego, co nieskończone i tego, co ograniczone, a istniejąca jednostka jest zarazem nieskończona i ograniczona"14. Kierkegaard w tych rozważaniach antropologicznych nie nawiązuje do antropologii Pawłowej, która podkreśla również ułomność, niedoskonałość człowieka, ale lokuje ją w tym, co cielesne. Natomiast wedle Kierkegaarda człowiek jest niedoskonały, „ułomny” ze względu na niedoskonałość także wyposażenia duchowego, wymagającego od jednostki wysiłku w pracy nad sobą i indywidualnych decyzji, jako że człowiek jest „wolny $\mathrm{w}$ duchu"15. Właśnie $\mathrm{z}$ powodu swojej niedoskonałości duchowej - duszy-jaźni i niewiedzy towarzyszy człowiekowi w jego działaniach i decyzjach lęk ${ }^{16}$, ale zarazem posiada on możliwość dążenia do transcendentnej doskonałości. Według Kierkegaarda egzystencji nie powinno brakować „powagi i pozytywności”, nie powinna ona być powierzchownym podejściem do faktów życia toczącego się dookoła i przykuwającego naszą uwagę coraz to nowymi ciekawostkami ${ }^{17}$. Egzystencja bowiem łączy się z bojaźnią, z bólem i cierpieniem, jest wyzwaniem, któremu towarzyszą dźwięki „muzyki wojennej”, budzącej nas do podjęcia decyzji póki jest na to czas - decyzji o skierowaniu się ku pozytywności egzystencji, która dopełnia życie tu i teraz, w tym elementy negatywne życia doczesnego ${ }^{18}$.

Jak zauważa Kierkegaard, w ówczesnej refleksji do istnienia podchodzi się $\mathrm{w}$ dwojaki sposób. Zgodnie $\mathrm{z}$ potocznym myśleniem można "uczynić wszystko, by zapomnieć o swoim istnieniu”, co jest o tyle „komiczne”, że „istnienie posiada tę dziwną właściwość, że istniejący istnieje czy tego chce, czy nie"19. Można też przyjąć postawę diametralnie różną od tej pierwszej - oto „istniejący może całą uwagę skupić na tym, że istnieje" i w następstwie zapomina "co to znaczy być człowiekiem" 20 . Według Kierkegaarda ta druga postawa jest z kolei typowa dla ówczesnej filozofii "spekulatywnej" (czyli między innymi dla Hegla), poszukującej w tym, co jednostkowe i konkretne - tego, co ogólne i abstrakcyjne.

14 Por. S. Kierkegaard, Concluding Unscientific Postscript to the "Philosophical Fragments", trans. D.F. Swenson, ed. W. Lowrie, Princeton 1968, s. 350.

15 Por. S. Kierkegaard, Albo-albo, op. cit., t. II, s. 17, tekst Estetyczna ważność malżeństwa.

16 Por. tamże, s. 465, tekst Ultimatum.

17 Por. S. Kierkegaard, Etapes sur le chemin de la vie, trad. F. Prior, M.H. Guignot, Paris 1948, s. 399.

18 Por. tamże, s. 399-400.

19 S. Kierkegaard, Wybór tekstów, w: K. Toeplitz, Kierkegaard, op. cit., s. 243, tekst Systemu odzwierciedlającego rzeczywistość nie można stworzyć.

20 Tamże. 
Można wskazać dwie główne interpretacje terminu "egzystencja", podstawowego w rozważaniach Kierkegaarda - pierwszą, która rozpatruje zagadnienie egzystencji w odniesieniu do sfery transcendencji, oraz drugą, która uznaje egzystencję za pewną cechę antropologiczną, a nawet za cechę istotową człowieka. Egzystencja byłaby pewną możliwością domagającą się aktualizacji, osiąganą zawsze indywidualnie dzięki wysiłkowi, przede wszystkim dzięki odnajdywanym odpowiedziom na pytania etyczne, oraz dzięki poszukującej, twórczej postawie jednostki i jej działaniom.

Pierwszy rodzaj interpretacji proponuje między innymi Roberts, wychodząc od tradycji Arystotelesa i od koncepcji egzystencji świętego Tomasza z Akwinu. Celem Robertsa jest interpretacja myśli Kierkegaarda jako następcy Arystotelesa i Tomasza Akwinaty. „W takiej lekturze "subiektywność" i "egzystencja" pociągają za sobą myślenie raczej o własnościach [cechach istotowych] niż o subiektywizmie i radykalnym wyborze"21 [podkr. R. Roberts]. Interpretacja Robertsa znajdowałaby prawomocność w cytowanych już słowach Kierkegaarda, że Boga „essentia involvit existentiam"22 - Boża esencja spowija istnienie.

$\mathrm{Z}$ niejednoznacznością kategorii egzystencji w myśli Kierkegaarda badacze łączą ironiczną postawę, która charakteryzowałaby, zdaniem Duńczyka, nasz sposób istnienia wraz z jego poznaniem oraz łączyłaby się z koncepcją prawdy subiektywnej jako opartej na paradoksie. Kierkegaard tak pisal o ironicznym zaangażowaniu i zarazem zdystansowaniu, o pozytywnej ironicznej postawie wobec świata tu i teraz - doczesnej rzeczywistości immanentnej: „Ale to, co odnosi się do egzystencji poetyckiej, w pewnej mierze odnosi się do życia każdej poszczególnej jednostki" - „Życie poetyckie rozpoczyna się dopiero wtedy, gdy poeta zaznajomi się ze swą epoką, włączy się w nurt jej życia i będzie pozytywnie wolny w tej rzeczywistości, do której sam przynależy"23 [podkr. Kierkegaard], czyli wtedy, gdy dzięki ironii uzyska dystans w stosunku do tego, co doczesne i do społeczności. Społeczność bowiem w swej masie, „tłum jest nieprawdą"24 (1848) i „aby stać się świadomym prawdy” - prawdy pojętej jako źródłowo subiektywna, zindywdiualizowana - „konieczne jest «pozosta-

${ }^{21}$ R.C. Roberts, Existence, emotion, and virtue: Classical themes in Kierkegaard, w: The Cambridge Companion to Kierkegaard, ed. by A. Hannay, G.D. Marino, Cambridge 1998, s. 177.

${ }^{22}$ S. Kierkegaard, Okruchy filozoficzne. Chwila, op. cit., s. 49, rozdział Absolutny paradoks.

${ }^{23} \mathrm{~S}$. Kierkegaard, O pojęciu ironii $z$ nieustajacym odniesieniem do Sokratesa, przekł. A. Djakowska, Warszawa 1999, s. 317, fragment Ironia jako moment opanowany. Prawda ironii.

${ }^{24}$ S. Kierkegaard, Dziennik (wybór), op. cit., s. 136. 
wanie na uboczu»"25 (1854). W Dzienniku pojawiają się więc zapiski, które powracają w drukach ulotnych w cyklu Chwila (Řieblikket), gdzie ludzki tłum czy nawet społeczność jest ujmowana nie tyle jako trzoda pasterza, poszukująca wiary i wiedzy, ale jako ślepe i zabłąkane stado. „Przeciętność jest zasadą, która kształtuje zwartq masę gatunku ludzkiego. I to, co bezwarunkowe, a zatem także Bóg, muszą żądać, jako pierwszego warunku wejścia $\mathrm{w}$ relację $\mathrm{z}$ ludźmi, ich rozdzielenia" 26 [podkr. Kierkegaard], czyli zróżnicowania, którego dokonują oni sami, wybierając projekt egzystencji.

Według Kierkegaarda postawa ironiczna łączyła się ze specyficznie przez niego pojmowaną dialektyką. "Charakterystyczne dla Kierkegaarda” byłoby „ „dialektyczne», czyli wielostronne” rozpatrywanie „zagadnienia, które pozornie wygląda na wewnętrznie sprzeczne"27. Egzystencja jednostki w koncepcji Kierkegaarda, również ujęta ironicznie, równała się „uświadomieniu własnej podmiotowości, namiętnemu skupieniu uwagi na egzystowaniu, utrzymywaniu rozdzierających człowieka sprzeczności w ryzach"28, między innymi dzięki ironicznemu, dialektycznemu ich ujmowaniu w stawaniu się. Zatem swoją koncepcję egzystencji Kierkegaard rozpatrywał jako uwikłaną w różnorakie sprzeczności, nie dające się usunąć, które rozpatrywał jako dialektyczne - wbrew Heglowskiemu pojmowaniu dialektyki i Aufhebung. Wchodził więc w dyskusję z Heglowską dialektyką, a zarazem z koncepcją konieczności dziejowej i z prymatem ogólności nad tym, co jednostkowe. Jednocześnie wskazywał źródła dialektyki w myśli Platona. Uwagi krytyczne Duńczyka wobec Hegla dotyczyły w szczególności deterministycznego ujmowania procesu dziejowego i historiozofii.

Można wskazać elementy egzystencji, dialektycznie ujmowane przez Sørena Kierkegaarda - jako nie tyle opozycyjne wobec siebie, co wzajem dopełniające się, i zarazem niesprzeczne, bowiem nie są wzajem wykluczające. Byłyby to:

1. wybór i wolność a konieczność (polemika z dialektyką i determinizmem dziejowym Hegla);

2. czas i chwila a wieczność (porządek chronologiczny a porządek logiczny);

3. immanencja doczesnej rzeczywistości rzeczy (upływającego czasu) a transcendencja idei (wieczności);

4. jednostkowość i poszczególność a powtórzenie i podwojenie;

25 Tamże, s. 142.

26 Tamże, s. 103.

27 Tamże, s. 96, przypis A. Szwed.

${ }^{28}$ E. Kasperski, Kierkegaard. Antropologia $i$ dyskurs o cztowieku, Pułtusk 2003, s. 223 . 
5. bezpośredniość tego, co estetyczne, a zapośredniczenie tego, co etyczne i religijne;

6. bezpośredniość humoru a pośredniość ironii w obrębie komunikacji i w stosunku subiektywności do siebie i innych;

7. tymczasowość i umowność znaków oraz znaczeń (wzorca) w obrębie komunikacji społecznej a trwała idea (oryginał), przywoływana w tej komunikacji, manifestująca się częściowo w postaci ideału (artystycznego, moralnego, osobowego).

\section{Wybór egzystencjalny}

Jedna z podstawowych tez Sørena Kierkegaarda dotyczy kwestii zawsze jednostkowego, indywidualnego wyboru własnej, świadomej egzystencji i jej celów, a dokonywanego na mocy różnych kryteriów w zależności od „stadium życia”. W Albo-albo (Enten-Eller), jednej ze swoich publikacji pseudonimowych, Kierkegaard wskazywał zasadnicze trzy stadia życia, oparte odpowiednio na estetycznym, etycznym oraz religijnym wyborze. Stadia te były jednak poprzedzone sytuacją egzystencjalną, w której jednostka nie była świadoma ani konieczności, ani możliwej wolności podejmowanych wyborów. Byłoby to stadium wstępne nie tyle egzystencji, co życia-istnienia jednostki, pozbawionej jeszcze w ogóle świadomości dotyczącej wyboru, decyzji i możliwych punktów odniesienia własnej egzystencji. Egzystencja bowiem rozpoczyna się wedle Kierkegaarda wraz z podejmowanym świadomie przez jednostkę, zawsze indywidualnym wyborem, dotyczącym dalszego istnienia. Kierkegaard pisze o rozwijaniu swojej refleksji wewnętrznej29, a wraz z tym historii wewnętrznej, łączonej przez niego z transcendentnymi koniecznościami i zarazem $\mathrm{z}$ wolnością. Historia wewnętrzna rozpoczynałaby się od pierwszej decyzji, od wolnego wyboru, który jest początkiem świadomej egzystencji ${ }^{30}$. Kierkegaard pisal: „Człowiek w chwili wyboru znajduje się więc przy końcu drogi rozwojowej, ponieważ jego osobowość zespala się, mimo to można powiedzieć, że jest właśnie na początku drogi, ponieważ wybiera samego siebie podług swojej wolności"31. Wybór ów również wpływa na interpretację swojej przeszłości, a więc dotyczyłby również własnej historii i biografii. Kierkegaard uważa, wbrew tezom Hegla, że w historii jako nauce, ujmującej jakiś domniemany konieczny porządek dziejów, „nie ma rzeczywistych wyborów «albo-albo». Wszystko jest bowiem w niej zmediatyzowane. Nie ma również rzeczywistych wyborów

29 Por. A. Szwed, Między wolnościq a prawdq egzystencji. Studium myśli Sørena Kierkegaarda, op. cit., s. 63.

${ }^{30}$ Por. tamże, s. 51-53.

31 S. Kierkegaard, Albo-albo, op. cit., t. II, s. 341.

129 Powtórzenie w myśli Sørena Kierkegaarda 
w dziedzinie przedmiotowego myślenia o rozgrywających się w niej zdarzeniach i procesach, ponieważ myślenie takie "przeskakuje» przeciwieństwa i zmierza do uogólnień, do syntez. Jedyną prawdziwą domeną wyborów była zatem według niego domena wolności, jedyną prawdziwą domeną wolności - subiektywne, wewnętrzne życie jednostki, w którym stawało się możliwe absolutne "albo-albo""32, wybór między estetycznie nacechowanym istnieniem a etycznie nacechowaną egzystencją.

Kierkegaard charakteryzuje sytuację «albo-albo" jako egzystencjalną sytuację wyboru, zaś „dokonanie właściwego wyboru” jako „sprawdzenie samego siebie" 33 . Takiego wyboru dokonujemy wiele razy w życiu - wyboru siebie - i ma on charakter estetyczny, jeśli jest dokonywany w imię chwili, a nie jest uświadamiany jako ostateczny, etyczny. Wybór taki powinien być dokonany „Z niekłamaną powagą" 34 . Człowiek zaangażowany w życie codzienne i w świat zewnętrzny z jego zmiennymi i podważalnymi normami traktuje życie jak spektakl i jak grę. Kierkegaard pisze: „życie jest maskaradą, a ta stanowi dla ciebie niewyczerpalne źródło konwersacji i dotychczas nie udało się jeszcze nikomu poznać cię naprawdę" 35 , nawet tobie samemu ze względu „na utrzymanie tego przebrania" 36 . Nie mogąc się rozpoznać, rozpoznawszy jednak samą konieczność wyboru siebie, wciąż nie posiadasz w pełni samodzielnie wybranych treści świadomości, ,jesteś niczym, a jesteś w stałym związku z innymi ludźmi, i to, czym jesteś, zawdzięczasz tym właśnie powiązaniom”, relacjom, które każdego $\mathrm{z}$ nas określają zanim nie podejmiemy próby wyboru własnej tożsamości, która jest wedle Kierkegaarda pewnym zadaniem. Ow stan świadomości pozbawionej trwałych i indywidualnie wybranych treści Kierkegaard ujmuje również jako pewien stan zagubienia - rozproszenia Ja wypełnionego zróżnicowanymi i zmiennymi treściami ${ }^{37}$.

\section{Biografia jako ujęcie wiedzy o egzystencji - opowieść a przypowieść}

Tematem dalszych rozważań jest podwojenie, powtórzenie - kategoria bardzo ważna w filozofii Sørena Kierkegaarda. Struktura powtórzenia to struktura dialektyczna, a dialektykę tę odnajdujemy również

32 E. Kasperski, Ironiczna antropologia. Rozdwojenie $i$ podwojenie cztowieka $u$ Kierkegaarda, op. cit., s. 185.

${ }_{33} \mathrm{~S}$. Kierkegaard, Albo-albo, op. cit., t. II, s. 209, tekst $O$ równowadze między tym, co estetyczne, i tym, co etyczne.

${ }_{34}$ Tamże, s. 210.

35 Tamże.

36 Tamże, s. 211.

37 Tamże, s. 213. 
w komunikacji oraz w ironii jako specyficznej relacji myśli i języka. Powtórzenie jest dialektyczne, bowiem jest duplikacją - naśladownictwem, mimesis w czasie i duplikacją w sensie powtórzenia struktury, czyli pewną odmianą analogonu, opisywaną przez Kierkegaarda. Jest zarazem dialektycznym związkiem pozytywności i negatywności, gdzie negatywność nie stanowi zaprzeczenia tego, co pozytywne, opartego na relacji sprzeczności. Jest to dopełnienie w postaci pewnego odbicia idei, ideału czy wzorca, który traci w ten sposób tożsamość, a zyskuje na różnicy - na swojej odmianie. Można też powiedzieć, że w przypadku powtórzenia jednostkowego przedmiotu ów przedmiot w swej jednostkowości zyskuje walor pewnego wzorca, zaczyna rościć sobie prawo do pewnej ponadjednostkowości czy nawet ogólności wraz z powtórzeniem. Wzorcem dzięki powtórzeniu zatem nie jest jedynie wzorzec osobowy i biograficzny, ujęty w czasie, ale również wzorzec przedmiotowy ujęty dzięki duplikacji (w przedstawieniu kulturowym, w reprodukcji) jako pewien model pozaczasowy - rzeczowy, bytowy wzorzec dla przedstawienia rzeczy, bytu.

Powtórzenie było rozpatrywane przez Kierkegaarda między innymi jako naśladownictwo, ale zarazem jako warunek wprowadzenia do kultury elementu nowości. Byłoby to powtórzenie pojęte jako naśladownictwo wzorców, służących wytwarzaniu przedmiotów kultury (w tym dzieł sztuki), ale zarazem jako pewne odstępstwo czy raczej modyfikacja zastanych wzorców - realizowanych indywidualnie. Kierkegaard w swoich rozważaniach na temat podwojenia, powtórzenia, nie wspomina wprost o Deuteronomium - Księdze Powtórzonego Prawa, ale trzeba podkreślić znaczenie tej księgi biblijnej w pracach Duńczyka. Należy przypomnieć, że w Deuteronomium - w Księdze Powtórzonego Prawa jest wskazany podwojony charakter aktu założycielskiego - powtórzenie przekazania tablic Mojżeszowi [9.8 oraz 10.1-10.5]. Teksty Kierkegaarda pisane w okresie, gdy opatrywał je pseudonimami, nawiązują przede wszystkim do Starego Testamentu. Kierkegaard podejmuje w nich, szczególnie w Bojaźni $i$ drżeniu i w Chorobie na śmierć, zagadnienie prawa danego przez Boga - podporządkowanie się człowieka temu prawu. Pisze tam również o ciąglej aktualizacji tego prawa - „orędzia”, odnoszonego do „dzisiaj” czasów Mojżesza, jak i do „czasów Księgi Powtórzonego Prawa”, ale także do „dzisiaj” czytającego Biblię̧38.

Niels Nymann Eriksen w swojej interpretacji myśli Kierkegaarda przywołuje rozróżnienie między nakazami i zakazami prawa a słowem i przekazem ewangelicznym w tradycji luteranizmu - rozróżnienie, które

38 Por. M. Czajkow ski, Egzystencjalna lektura Biblii, Lublin 1993, s. 58-59. 
nie jest podkreślane w myśli Kierkegaarda, ale jednak jest tam obecne ${ }^{39}$. Prace z późniejszego okresu, dotyczące przede wszystkim problematyki religijnej (między innymi teksty ulotne zebrane w Chwili), odnoszą się do Nowego Testamentu, zawierającego apostolskie świadectwa przesłania Chrystusa na temat laski. Rozważania dotyczące Nowego Testamentu skupiają się w dużej mierze na charakterystyce Chrystusa jako Boga-człowieka i na trudnościach - paradoksach wiary, pojawiających się wobec takiego wydarzenia - zarazem historycznego, w porządku doczesności w rzeczywistości immanentnej świata ludzi, oraz wydarzenia ponadczasowego, w porządku wieczności. Wydarzenie to jest rozpatrywane jako element „historii świętej” 40 , która sama jest paradoksalna, a powinno być rozważane $\mathrm{w}$ kategoriach transcendencji - rzeczywistości transcendentnej. Nie jest ona dostępna człowiekowi poznawczo, na mocy argumentacji, ale staje się dostępna dzięki wierze, czyli - wedle Kierkegaarda - dzięki postanowieniom tych, którym dane jest wierzyć zarazem na mocy własnej decyzji i z wyboru Boga. W pracach późniejszych, dotyczących chrześcijaństwa, pojawia się również motyw powtórzenia. Jest to powtórzenie pewnych wątków ze Starego Testamentu w Nowym Testamencie, rozpatrywanie sfery immanencji, doczesnej rzeczywistości Natury i człowieka jako pewnego powtórzenia sfery transcendencji, ale przede wszystkim rozpatrywanie przykładu Chrystusa (obok Sokratesa) jako pewnego wzorca Nauczyciela, którego decyzje i działania powinny być powtarzane przez „prawdziwych”, wybranych do wiary chrześcijan.

Przedmiotem analiz są tu zatem zróżnicowane tezy Sørena Kierkegaarda, dotyczące powtórzenia, w tym również ironii. Objaśniając stanowisko Kierkegaarda, należy odwołać się do ustaleń Gilles'a Deleuze'a na temat powtórzenia i różnicy oraz do jego komentarzy na temat prac Sørena Kierkegaarda i Friedricha Nietzschego. Kwestia powtórzenia u wymienionych autorów łączy się ściśle $\mathrm{z}$ zagadnieniem indywiduali$\mathrm{zmu}$. Pytanie o powtórzenie można formułować jako zarazem pytanie o indywidualny charakter realizacji wzorca kulturowego - jego powtórzenie, a jednocześnie modyfikację. Wiąże 'się z tym problematyka kulturowej normatywności - normy artystycznej i estetycznej w ocenie przedmiotów kultury, ale też norm obyczajowych i moralnych, tak ważnych w rozważaniach Kierkegaarda na temat relacji estetyki i etyki. Pytanie, które łączy się z problematyką powtórzenia i u Kierkegaarda, i u Deleuze'a, dotyczy specjalnego statusu dzieła sztuki wśród przedmiotów kultury - jego roli w modyfikowaniu zastanych wzorców kultury.

${ }^{39}$ Por. N. Nymann Eriksen, Kierkegaard's Category of Repetition. A Reconstruction, Berlin, New York 2000, s. 133.

${ }^{40}$ Por. S. Kierkegaard, Wybór tekstów, w: K. Toeplitz, Kierkegaard, op. cit., s. 251, przypis K. Toeplitz, s. 256-257. 
Można wskazać inspiracje tezami Kierkegaarda, obecne w rozważaniach Deleuze'a na temat specjalnego statusu sztuki (znaków sztuki) w kulturze. Należy podkreślić założenia indywidualizmu, tak ważne w koncepcjach trzech wspomnianych filozofów - Kierkegaarda, Nietzschego i Deleuze'a. To one pozwalają określać powtórzenie jako indywidualną realizację wzorca - jako jego modyfikację czy też wprowadzenie elementu nowości.

Powtórzenie rozpatrywał Kierkegaard jako pewną szczególną postać podwojenia, duplikacji. Jak pisze Edward Kasperski, „podwojenie było dla Kierkegaarda strukturą uniwersalną, znamionującą człowieka, odtwarzaną w sposób swoisty w różnych formach jego egzystencji, poddawaną w nich rozmaitym modyfikacjom, aczkolwiek zachowującą w nich pewną ciągłość i stałość"41. „Podstawową matrycą podwojenia” byłaby „struktura ironii”42. „Podwójność [duńs. fordoblelse] stanowiła dla Kierkegaarda bycie kimś jednym i równocześnie kimś drugim, występowanie w człowieku sprzecznych właściwości i zespolenie ich"43. Podwojenie występuje tu w znaczeniu „dwoistości stosunku, w którym zostają zespolone dwie odrębne wartości" 44 , a było rozpatrywane przez Kierkegaarda również jako składnik jego „ironicznej antropologii” i miało „swoje oparcie w praktyce pisarskiej" samego Kierkegaarda ${ }^{45}$, w jego koncepcji autorstwa pseudonimowego, realizowanej w pracach $\mathrm{z}$ lat 1838-1846.

Można powiedzieć, że Kierkegaard rozpatruje podwójność - duplikację w odniesieniu do dwóch wskazywanych przez siebie porządków rzeczywistości. W kontekście doczesnej rzeczywistości immanentnej podwojenie przybiera postać powtórzenia w planie czasowym, diachronicznym, czyli powtórzenia jako pewnego następstwa (podwojenie, powtórzenie wzorca). Natomiast w odniesieniu do rzeczywistości transcendentnej jest to podwojenie w planie wieczności, można powiedzieć - podwojenie w porządku zawsze synchronicznym, strukturalnym, które okazuje się samą ideą podwojenia w ogóle. Kierkegaard dostrzega nakładanie się obu tych porządków rzeczywistości w naszej egzystencji i w jej poznaniu, a więc wraz z tym - nakładanie się powtórzenia w planie diachronii i podwojenia $w$ planie synchronii. Byłoby to powtórzenie podwojenia, czyli re-duplikacja w czasowym planie rzeczywistości tu i teraz.

Kierkegaard zatem wyróżnia dwa rodzaje podwojenia-powtórzenia: strukturalne i diachroniczne. Powtórzenie diachroniczne ma

41 E. Kasperski, Ironiczna antropologia. Rozdwojenie $i$ podwojenie człowieka u Kierkegaarda, op. cit., s. 190.

${ }^{42}$ Por. tamże, s. 191.

43 Tamże, s. 180.

44 Por. tamże.

45 Por. tamże, s. 181.

133 Powtórzenie w myśli Sørena Kierkegaarda 
charakter czasowy i jest to na przykład naśladowanie, w szczególności wzorców osobowych - Chrystusa (stadium religijne) i Sokratesa (stadium etyczne) lub osób publicznych (w szczególności postaci sztuk teatralnych, kreowanych przez aktorów, jak i samych aktorów jako postaci życia publicznego). Kierkegaard dokonuje rozróżnienia między ideą (transcendencja) i ideałem (realizacja idei w immanencji życia doczesnego) oraz wzorcem (pewna personifikacja, uosobienie idei, realizowanej przez konkretną osobę - wzorzec osobowy ${ }^{46}$ ). Rodzajem naśladowania jest również wspomnienie i przypominanie, ale też poszukiwanie powtórzenia estetycznego - doznań zmysłowych z przeszłości. Kierkegaard, krytykując sprowadzanie powtórzenia tylko do takiego czasowego jego ujęcia, opisuje w Powtórzeniu (Gjentagelse) porażkę narratora, który wciąż zawodzi się na estetycznym powtórzeniu przeżyć z przeszłości, by ostatecznie zwątpić w ogóle w możliwość powtórzenia. Natomiast powtórzenie strukturalne dotyczy przede wszystkim relacji bytu i myśli, czyli niejako powtórzenia bytu w przedstawieniu. Jest to również powtórzeniowa struktura dialektycznej komunikacji egzystencjalnej - przekazywanie wiedzy i zaświadczanie o wierze, oparte na powtarzaniu doświadczeń nauczyciela czy wzorca, danych dzięki wiedzy. Zatem również wzorzec biograficzny (nie cechy osobowe, ale podejmowane decyzje i wybory etyczne, religijne jako element biografii) jest rozpatrywany przez Kierkegaarda w kategoriach powtórzenia.

Kierkegaard, rozpatrując kwestie poznawcze wraz z kwestiami komunikacji, wprowadził pojęcie „refleksji podwójnej” (Dobbelt-Reflexionen). Podwojenie jaźni i podwojenie egzystencji stanowiło w filozofii i antropologii Kierkegaarda podstawowy element definicji człowieka ${ }^{47}$. „Bez możliwości wewnętrznego podwojenia i posługiwania się podwojeniem postulowana realizacja człowieka w człowieku", egzystencji w jednostkowym istnieniu była wedle Kierkegaarda „niemożliwa. Brak podwojenia sprawiał, że stawanie się jednostki pokrywało się wówczas ze stawaniem się biologicznym, z ilościowym wzrostem wiedzy i umiejętności"48, ale także z biograficzną zmiennością losów jednostki. Dlatego biografia jednostkowa wymagała doczesnego wzorca biograficznego jako pewnej wskazówki albo też religijnej czy mitycznej przypowieści, w której można dopatrzyć się nie tylko zmiennych losów, ale trwałych i stałych idei-wartości jako punktów odniesienia wyborów, decyzji i działań jednostki. Egzystencjalne powtórzenie, które stało się przedmiotem rozważań w tekś-

${ }^{46}$ Por. S. Kierkega ard, Okruchy filozoficzne. Chwila, op. cit., s. 236, Chwila nr 5, fragment Geniusz - chrześcijanin.

47 Por. E. Kasperski, Kierkegaard. Antropologia $i$ dyskurs o czlowieku, op. cit., s. 308.

48 Por. tamże. 
cie Powtórzenie [Gjentagelse, 1843], Kierkegaard rozpatrywał jako jedną z postaci podwojenia - podwojenie, które uwzględnia następstwo czasowe czy współwystępowanie w czasie, a dotyczy przede wszystkim sfery przeżyć i doświadczeń uwewnętrznionych. Podwojenie było zarazem rozpatrywane przez niego jako pewne „rozszczepienie” czy „podział” jednostki49.

Podwojenie w pisarstwie samego Kierkegaarda przejawiało się „w polimorfizmie tekstowych osobowości autorskich, w ich różnorodności, powiązaniu ich relacjami dialogowymi" 50 , ale też w formule autobiograficznej (przede wszystkim listów) i w autorstwie pseudonimowym. Dlatego można mówić - w przypadku filozoficznego pisarstwa Kierkegaarda o pewnym „podwojeniu autorstwa" 51 . Podwojenie przejawiało się „w usamodzielnieniu różnych aspektów osobowości autorskiej”, jak tė̇ „w ich dialogowym spotkaniu i zderzeniu”. Według Kasperskiego, „przedłużeniem podwojenia była polifonia, słowo wielogłosowe i dialog w twórczości pisarskiej" Kierkegaarda ${ }^{52}$. Kasperski wskazuje cztery aspekty rozważań Kierkegaarda na temat podwojenia i powtórzenia, duplikacji i re-duplikacji. Byłby to aspekt filozoficzny (teoretyczny), etyczno-religijny, autorsko-pisarski oraz hermeneutyczno-egzystencjalny ${ }^{53}$. Jak się wydaje, rozważania religijne i egzystencjalne stanowiłyby pewien punkt odniesienia ze względu na odnoszenie się $w$ nich do sfery transcendentnej ideiwartości. Jednak kwestie „filozoficzne” czy też „teoretyczne” były również rozstrzygające. Odniesienie do postaci Sokratesa, to zarazem u Kierkegaarda odwolanie do kwestii ironii i jej pewnej logicznej „matrycy”. „Wyróżnione typy podwojeń odsyłały strukturalnie do ironii, która tworzyła dla nich rodzaj matrycy, wzorca"54. Można również odnaleźć w rozważaniach Duńczyka pewne „podwojenie metafizyczne”. Podwojenie to występowało u Kierkegaarda w dwóch głównych postaciach. W pierwszym przypadku „chodziło o rozszczepienie, podwojenie i przekształcenie dyskursu teoretycznego"55. Natomiast w drugim przypadku, już wspominanym powyżej, podwojenie było rozpatrywane w odniesieniu do „odrębnych dziedzin kategorialnych" myśli i bytu ${ }^{56}$.

Specjalnym rodzajem podwojenia było - według Kierkegaarda - „podwojenie etyczno-religijne”, które dotyczyło ludzkiej jednostkowości i isto-

49 Por. tamże, s. 310.

50 Tamże, s. 313.

61 Tamże, s. 314

52 Por. tamze.

53 Por. tamże, s. 315.

54 Tamże.

55 Tamże, s. 318.

56 Por. tamże.

135 Powtórzenie w myśli Sørena Kierkegaarda 
ty tego, co człowiecze, czyli definicji antropologicznej. Podwojenie to „oznaczało pewien szczególny” dla ludzkich jednostek „sposób istnienia, w którym urzeczywistniały one własną podmiotowość”’ ${ }^{2}$. Zgodnie z postulata$\mathrm{mi}$, dotyczącymi etycznego oraz religijnego sposobu istnienia - jednostki decydujące się na życie wedle wyborów etycznych i przesłanek religijnych, miały uzyskiwać właśnie wiedzę o owym podwojeniu - o egzystowaniu niejako „w dwóch jakościowo różnych rzeczywistościach”58 w świecie immanencji, społecznych i kulturowych ustaleń, norm przyjmowanych i uznawanych tu i teraz, ale zarazem w ciągłym odnoszeniu się jednostki-subiektywności do świata transcendencji.

Kierkegaard, pisząc o powtórzeniu, często podkreślał, że powtórzenie „jest to bez wątpienia jedno z najważniejszych zadań nowej filozofii" Pisał w swoim Dzienniku: „Pierwszym wyrazem relacji pomiędzy bezpośredniością a pośredniością jest powtórzenie. W bezpośredniości nie ma powtórzenia; sądzić można, że bezpośredniość tkwi w różnorodności rzeczy. Bynajmniej, gdyby wszystko w świecie było absolutnie identyczne, nie byłoby jeszcze powtórzenia"60 [1842-43] [podkr. Kierkegaard]. Koncepcja powtórzenia pojawia się $\mathrm{w}$ pracach Kierkegaarda wielokrotnie. Podsumowując, można wskazać trzy sposoby określania powtórzenia: 1) w odniesieniu do dialektyki Hegla jako pewnej koncepcji powtórzenia i różnicy, 2) w odniesieniu do koncepcji retorycznych i komunikacyjnych - jako zagadnienie ironii, 3) w odniesieniu do egzystencji jednostkowej, indywidualnej, do zagadnienia woli i wyborów, które zarazem składają się na wspólnie konstruowany świat społeczny i kulturowy.

Gilles Deleuze w swoich rozważaniach o różnicy i powtórzeniu podkreśla, że Kierkegaardowi nie chodzi o wydobywanie z powtórzenia „czegoś nowego”, chodzi o to, „by działać, by z powtórzenia jako takiego uczynić coś nowego, czyli wolność i zadanie wolności”61, o to, by „przeciwstawić następnie powtórzenie prawom Przyrody. Kierkegaard oświadcza, że nie mówi bynajmniej o powtórzeniu w przyrodzie, o cyklach lub porach roku”, ale wedle niego powtórzenie "dotyczy tego, co w woli najbardziej wewnętrzne” (czyli indywidualne, subiektywne), jako że „wszystko zmienia się wokół woli, zgodnie $\mathrm{z}$ prawem przyrody. Zgodnie $\mathrm{z}$ prawem przyrody powtórzenie jest niemożliwe"62. Powtórzenie nie jest bowiem

57 E. Kasperski, Ironiczna antropologia. Rozdwojenie $i$ podwojenie cztowieka $u$ Kierkegaarda, op. cit., s. 184.

58 Tamże, s. 185.

${ }^{59}$ S. Kierkegaard, Powtórzenie, przekl. B. Swiderski, Warszawa 1992, s. 49.

60 S. Kierkegaard, Dziennik (wybór), op. cit., s. 113.

61 G. Deleuze, Różnica i powtórzenie, przekł. B. Banasiak, K. Matuszewski, Warszawa 1997, s. 33 .

62 Tamże. 
rozpatrywane jako zasada prawodawcza (dotycząca odkrywanego, poznawanego prawa przyrody), ale jako „zasada ustanawiająca”, bo dotycząca ustanawiania przez jednostkę i dzięki woli - świata właściwego człowiekowi i jego działaniom - świata kultury (chodzi o to „by działać). Powtórzenie zatem jest tu rozpatrywane w odniesieniu do tego, co kulturowe i jest związane ściśle $\mathrm{z}$ wolą i aktywnością indywidualną. Dlatego swoje rozważania o powtórzeniu Kierkegaard opatruje podtytułem „próba psychologii eksperymentalnej”. Powtórzenie jest bowiem elementem kultury jako obszaru działań człowieka o tyle, o ile jest elementem działań indywidualnych wraz $\mathrm{z}$ wyborami i przyjmowaną postawą wobec świata $\mathrm{i}$ innych.

Tematyka powtórzenia w pracach Sørena Kierkegaarda łączy się z zagadnieniem niepowtarzalności. Niepowtarzalność dotyczy istnienia poszczególnego, zawsze jednostkowego, ale także osobowości, czyli tego, co można uznać za istotowe w każdej jednostce ludzkiej, bowiem jaźń-dusza jest rozpatrywana jako to, co transcendentne i co wyraża się w zawsze indywidualnej osobowości. Kierkegaard wielokrotnie podkreśla rolę osobowości, szczególnie w tekście $O$ równowadze między tym, co estetyczne, $i$ tym, co etyczne oraz w pracy na temat lęku. Kierkegaard określa „chwilę” wyboru jako moment uświadomienia sobie pewnej konieczności, która pojawia się w tej właśnie „chwili” - w chwili teraźniejszej, w której splata się przeszłość i przyszłość, a potwierdzeniu - wyborowi podlega osobowość. Jest to splot, węzeł, punkt zwrotny, który przywodzi na myśl koncepcję kłącza Gilles’a Deleuze’a, zestawioną z pojmowaną linearnie ciągłością biografii. Ów moment wyboru i samookreślenia własnej osobowości, a zarazem indywidualnego istnienia, może być uznany jedynie za punkt kulminacyjny w dotychczasowej biografii, nie zaś za moment przełomu. Dzieje się tak, jeśli jednostka pozostanie nadal przy prymacie wartościowania estetycznego mimo możliwości ostatecznego wybrania tego, co etyczne i życia świadomego istnienia - egzystencji.

Søren Kierkegaard jednostkowe życie i zawsze indywidualną egzystencję - życie podmiotu świadomego własnego istnienia, rozpatruje jako niepowtarzalne, jedyne. Ta jednostkowość i jedyność egzystencji ma u podstaw wyodrębnienie, autonomię jednostki wobec doczesnego świata - immanencji rzeczywistości rzeczy i społeczności, innych. Jak pisał Kierkegaard, „pierwszym skutkiem wyboru jest totalne wyodrębnienie się, izolacja. Wybierając bowiem samego siebie, wyizolowuję siebie z moich stosunków ze światem, aż do zakończenia tego procesu w abstrakcyjnej tożsamości"63. Egzystencja jest tu rozpatrywana jako żmudne kon-

${ }^{63} \mathrm{~S}$. Kierkegaard, Albo-albo, op. cit., t. II, s. 325, tekst $O$ równowadze między tym, co estetyczne, i tym, co etyczne. 
struowanie własnej tożsamości i zarazem własnej biografii. Wyizolowanie jednostki nie ma jednak charakteru czasowego - czasowości podlegamy jako doczesnemu porządkowi powtórzenia, a zarazem jesteśmy w konieczny sposób uwikłani w relacje $\mathrm{z}$ transcendencją, ze sferą pozaczasowej wieczności, trwałości i ciągłości, gdzie powtórzenie przyjmuje postać nie czasowego następstwa, ale logicznego współwystępowania, podwojenia.

Można powiedzieć, że powtórzenie jest rozpatrywane przez Kierkegaarda przede wszystkim jako element jednostkowej egzystencji i jako takie jest uwikłane czasowo. To czasowe uwikłanie $\mathrm{i}$ egzystencji, i powtórzenia, Kierkegaard rozważa jako zarazem uwikłanie biograficzne. Byłoby to - można powiedzieć - uwikłanie narracyjne jednostki i jej egzystencji jako konstruowanie własnej biografii opartej na pow tórzeniu. Tu dopiero to, co jednostkowe, splata się - jakże inaczej niż $\mathrm{u}$ Hegla - z tym, co historyczne, między innymi dzięki powtórzeniu. Powtórzenie bowiem jest pewną koniecznością, ale dotyczącą prymarnie jednostkowej woli, wyborów i aktywności przede wszystkim psychicznej (świadomej). Jak zauważa Gilles Deleuze, „powtórzenie jawi się jako logos samotnika, jednostki, logos "myśliciela prywatnego». U Kierkegaarda i Nietzschego występuje przeciwieństwo myśliciela prywatnego, myśliciela-komety, nośnika powtórzenia, i profesora publicznego, doktora praw"64. Kierkegaard przeciwstawia tak pojęte powtórzenie wspomnieniu i przeżyciom, mającym charakter nowości. „Powtórzenie określa to, co Grecy nazywali «wspomnieniem». Mówili oni, że wiedza jest wspomnieniem, zaś nowa filozofia twierdzi, że życie to powtórzenie"65. I dalej: „Powtórzenie i wspomnienie to ten sam ruch, lecz skierowany w przeciwne strony”, bo „właściwe powtórzenie to wspomnienie zwrócone ku przyszłości”66. Wspomnienie wciąż odsyła nas do przeszłości, jest uobecnianiem przeszłości w teraźniejszości dzięki pamięci, ale nie dzięki działaniu, które czyniłoby w powtórzeniu to, co przeszłe - aktualnym. Natomiast nowość jest tym, co wciąż domaga się bycia nowym, a więc wyklucza powtórzenie w ogóle. Powtórzenie rozumiane jest przez Kierkegaarda jako odmienne od „zwyczaju i pamięci. W ten właśnie sposób powtórzenie staje się myślą przyszłości: przeciwstawia się starożytnej kategorii przypomnienia i nowoczesnej kategorii habitus"67. Kierkegaard, objaśniając swoje, niejako pośrednie stanowisko, pisze, że „dialektyka powtórzenia jest łatwa, bo to, co powtarza się, już było (w przeciwnym razie powtórzenie jest niemożliwe) i właśnie dlatego, że było - powtórze-

${ }^{64}$ G. Deleuze, Różnica i powtórzenie, op. cit., s. 34 .

65 S. Kierkega ard, Powtórzenie, op. cit., s. 49.

66 Tamże, s. 50.

${ }^{67}$ G. Deleuze, Różnica i powtórzenie, op. cit., s. 35. 
nie staje się nowością"68, czyli do naszych przeżyć i aktywności zostaje wprowadzona pewna modyfikacja, możliwa do dostrzeżenia dzięki powtórzeniu.

Kierkegaard, polemizując z dialektycznymi koniecznościami historii Hegla, pokazuje, że porządek powtórzenia, związany z jednostkową wolą i wyborami, jest pewną koniecznością, która jednak realizuje się zawsze indywidualnie. Mówiąc inaczej, powtórzenie jest dane zawsze jako to, co jednostkowe, poszczególne i szczególne, a dopiero wtórnie jest określane jako to, co powszechne czy ogólne. Kierkegaard zaznacza, że powtórzenie nie jest tym, co dane powszechnie w sposób oczywisty, ale że wymaga od jednostki pewnej postawy i wyboru między wspomnieniem, nowością a powtórzeniem, że łączy się z działaniem, podejmowanym jako skutek pewnych wyborów i postawy. Z kolei działania jednostkowe, składające się na jednostkową biografię, stanowią pewne biograficzne, czyli osobowe i egzystencjalne wzorce będące zarazem pewnymi wzorcami w obrębie danej kultury (dychotomia wzorca i łaski69, tego, co podlega wyborowi jednostki i tego, co jest od wyborów niezależne jako transcendentne).

Trzeba zaznaczyć, że wzorce kulturowe są rozpatrywane przez Kierkegaarda $\mathrm{w}$ pewnym powiązaniu $\mathrm{z}$ tezami psychologii jako wiedzy o duszy, a więc o tym, co transcendentne $w$ człowieku. Jest to powiązanie wzorców kulturowych z pewnymi cechami antropologicznymi - z nacechowaniem jego myślenia i zachowania, określanym między innymi jako nastrój (Stemning), troska (Sorg), lęk (Angest), ale też namiętność, pasja jako cecha poznania - procesów poznawczych. Te stany jaźni-duszy wpływają $w$ pewnym stopniu na tworzone, kształtowane i wybierane wzorce kulturowe, w szczególności wzorce osobowe. Można tu dopatrzyć się analogii z późniejszymi rozważaniami nad kulturą Wilhelma Diltheya czy antropologów kultury (na przykład Ruth Benedict), łączących badania nad kulturą z rozważaniami psychologicznymi, choć psychologia była wówczas już odrębną i ukształtowaną dziedziną nauki. Jako wzorce kulturowe, mityczne i zarazem biograficzne, a więc osobowe, Kierkegaard wskazywał postaci biblijne - Abrahama i Hioba. Jednak zarazem opisywal w swoich tekstach inne biografie, jak też tworzył biografie swoich autorów pseudonimowych (na przykład Constantina Constantinusa vel Constantiusa, narratora tekstu Powtórzenie). Można powiedzieć, że na podstawie tych dwóch typów wzorców osobowych, wzorców kulturowych, będących elementem albo przypowieści mitycznej, albo zwykłej opowieści narracyjnej, można określić powtórzenie jako naśladownictwo w obrębie kultury oraz jako modyfikację wzorca kulturowego. W przypadku mitycznych przypowieści i ich postaci Kierkegaard pod-

${ }_{68}$ S. Kierkegaard, Powtórzenie, op. cit., s. 66.

${ }^{69}$ Por. S. Kierkegaard, Dziennik (wybór), op. cit., s. 110. 
kreśla pewne analogie w mitycznych biografiach - podwojenia czy duplikacje. Gilles Deleuze pisze, że w odczytaniu Biblii przez Kierkegaarda „Hiob kwestionuje prawo w sposób ironiczny” - „usuwa to, co ogólne, by dotrzeć do tego, co najbardziej jednostkowe, jako do zasady, jako do tego, co powszechne. Abraham podporządkowuje się prawu humorystycznie, ale właśnie w tym podporządkowaniu odnajduje jednostkowość jedynego syna, którego prawo nakazywało mu poświęcič"70.

Biografie stanowiące element mitu, przypowieści podlegają dzięki powtórzeniu - pewnemu naśladownictwu, ponieważ ujmujemy własne życie w odwołaniu do mitu, który jest w ten sposób wciąż aktualizowany w powtórzeniu. Inaczej jest w przypadku zwykłych biograficznych opowieści - owych jednostkowych przypadków biografii (działań, wyborów, postaw), które Kierkegaard podaje jako przykłady w swoich wywodach. W ten sposób czyni on $\mathrm{z}$ nich pewne wzorce, ale zawsze indywidualne, jednostkowe i odrębne wobec naszej własnej biografii. Czytelnik pism Kierkegaarda powinien odnieść do nich własne działania, wybory, postawy, a w ten sposób odnaleźć pewne analogie i kreować te analogie w późniejszych swych działaniach, modyfikując przejęte osobowe i kulturowe wzorce. Wedle Kierkegaarda takich powtórzeń - analogii powinniśmy poszukiwać przede wszystkim we własnej biografii i kreować je, odwołując się do własnych działań, wyborów, postaw z przeszłości. Tak pojęte powtórzenie, jako modyfikacja działań z przeszłości, może uczynić naszą biograficzną narrację o egzystencji bardziej spójną, a nas - pewniejszymi własnych, jednostkowych wyborów i postaw, przesłanek działania. Jak pisze Kierkegaard, „kiedy twierdzimy, że życie [jednostkowe, a nie życie w ogóle; dop. M.G.] jest powtórzeniem, oznacza to, że egzystencja, która była, teraz się staje"71, czyli że nasza jednostkowa, indywidualna egzystencja (której jesteśmy częścią i której my podlegamy) dana jest nam jako możliwa do poznawczego ujęcia, bowiem podlega zarazem zasadzie i konieczności powtórzenia, zawsze danej jednostkowo, indywidualnie. „Największym pragnieniem wolności jest bowiem przywołanie Powtórzenia"72, czyli działanie w analogii do tego, co przeszłe, działanie, które jest pewną aktualizacją przeszłości. Umacnia to poczucie realności własnej egzystencji w jej wolnym i zarazem koniecznym stawaniu się.

Łatwo dostrzec, że Kierkegaard rozpatrywał biografię w formie opowieści jako pewien społeczny i kulturowy wzorzec o charakterze tymczasowym, umownym, w obrębie przyjętej społecznej i kulturowej norma-

${ }^{70} \mathrm{G}$. Deleuze, Różnica i powtórzenie, op. cit., s. 34-35.

71 S. Kierkega ard, Powtórzenie, op. cit., s. 66.

72 Tamże, s. 38, fragment List Constantina Constantiusa do Profesora Heiberga, kawalera orderu Dannebrog. 
tywności. Natomiast biografia w formie przypowieści mitycznej oraz religijnej (biblijnej) czyniłaby $\mathrm{z}$ jednostkowej historii bohatera $\mathrm{i} z$ niego samego - pewien ideał, czyli częściową manifestację idei (oryginału pozostającego $w$ sferze transcendencji) $w$ rzeczywistości immanentnej w doczesnej rzeczywistości tu i teraz. Dlatego Kierkegaard rozpatrywał mit jako to, co w pewien sposób konkuruje czy zagraża chrześcijaństwu, czyli religii (między innymi w Pojęciu lęku i w Chwili). Trzeba podkreślić, że Kierkegaard odwoływał się nie tylko do biblijnej historii Hioba (przede wszystkim w Powtórzeniu) i Abrahama (w Bojaźni i drżeniu). Wskazywał również mity greckie wraz ze starożytną tradycją i antyczną tragedią w szczególności (bohaterowie mitów greckich - Ifigenia i Agamemnon ${ }^{73}$ ) jako przypowieści biograficzne, które stanowią pewne punkty odniesienia biografii jednostkowej w tradycji zachodniej ${ }^{74}$. Byłyby to zatem pewne wskazania wyborów, decyzji i działań nowoczesnej podmiotowości, poszukującej swojej tożsamości, a wraz z tym autorytetów i wzorców osobowych, i ideałów.

${ }^{73}$ Por. S. Kierkega ard, Bojaźń i drżenie. Choroba na śmierć, op. cit., s. 61.

${ }^{74}$ Por. S. Kierkega ard, Albo-albo, op. cit., t. I, s. 155-156, tekst Odblask antycznego tragizmu w tragizmie wspótczesnym. 